Schumaker, P. and Kelly, M. (2012), "Ethics Matter: The Morality and Justice Principles of Elected City Officials and their Impact of Urban Issues." Journal of Urban Affairs, 34: 231-253. Publisher's Official Version available at:

http://dx.doi.org/10.1111/j.1467-9906.2011.00583.x Open Access version: http://kuscholarworks.ku.edu/dspace/.

[This document contains the author's accepted manuscript. For the publisher's version, see the link in the header of this document.]

\title{
Ethics Matter: The Morality and Justice Principles of Elected City Officials and their Impact of Urban Issues
}

\author{
By Paul Schumaker \\ University of Kansas \\ \& \\ Marisa Kelly \\ Ithaca College
}

\section{Paper citation:}

Schumaker, P. and Kelly, M. (2012), "Ethics Matter: The Morality and Justice Principles of Elected City Officials and their Impact of Urban Issues." Journal of Urban Affairs, 34: 231-253.

\begin{abstract}
:
This article pursues the thesis that ethics matter in urban policymaking. Interviews with 95 elected officials in 12 cities revealed the officials' support for-and opposition to-many principles of political morality and political justice. Officials regarded their ethical principles as almost as important as economic constraints on their policy decisions, and much more important than political, legal, jurisdictional, and cultural considerations. The role of ethics in the resolution of 93 issues that arose in their communities varied from minimal to decisive. On some occasions ethical considerations served mainly as justifications for policy decisions made primarily on other grounds. But more often, significant numbers of officials drew largely, and even primarily, on their own moral judgments when casting their votes on community issues. And some policies were driven by consensual moral understandings.
\end{abstract}


Schumaker, P. and Kelly, M. (2012), "Ethics Matter: The Morality and Justice Principles of Elected City Officials and their Impact of Urban Issues." Journal of Urban Affairs, 34: 231-253. Publisher's Official Version available at:

http://dx.doi.org/10.1111/j.1467-9906.2011.00583.x Open Access version: http://kuscholarworks.ku.edu/dspace/.

In Journal of Urban Affairs 34: 3 (August 2012), 231-54

Ethics Matter: The Morality and Justice Principles of Elected City Officials and their Impact of Urban Issues

\author{
Paul Schumaker, University of Kansas \\ Marisa Kelly, Ithaca College
}

\begin{abstract}
This paper pursues the thesis that ethics matter in urban policymaking. Interviews with 95 elected officials in 12 cities reveal their support for and opposition to many principles of political morality and political justice and that they regard their ethical principles as almost as important as economic constraints on their policy decisions, and much more important than political, legal, jurisdictional, and cultural considerations. In resolving 93 issues that arose in their communities, ethical considerations played little role on a few occasions. However, ethical principles were usually of some importance, ranging from being employed as justifications for policy decisions made on other grounds to having a significant impact on policies adopted to resolve issues. On some occasions, collective ethical judgments were at the center of policy resolutions.
\end{abstract}

Key words: Political judgment; theories of urban policymaking 
Schumaker, P. and Kelly, M. (2012), "Ethics Matter: The Morality and Justice Principles of Elected City Officials and their Impact of Urban Issues." Journal of Urban Affairs, 34: 231-253. Publisher's Official Version available at:

http://dx.doi.org/10.1111/j.1467-9906.2011.00583.x Open Access version: http://kuscholarworks.ku.edu/dspace/.

Author bios

Paul Schumaker is professor of political science at the University of Kansas. His work has been in the fields of political theory and urban politics. Among his prior books are Critical Pluralism, Democratic Performance, and Community Power (University Press of Kansas, 1991) and From Ideologies to Public Philosophies (Blackwell, 2008). He is currently interested in the reconstruction of pluralist theory and its applications to community politics.

Marisa Kelly is Provost and Vice President for Academic Affairs at Ithaca College. Prior to joining Ithaca College she served for five years as Dean of the College of Arts and Sciences and McQuinn Distinguished Chair at the University of St. Thomas in Minnesota. Dr. Kelly earned her doctorate in political science from the University of Kansas and spent 12 years as a faculty member at University of the Pacific, teaching and conducting research in the areas of political theory, American politics and administration, and urban politics, before moving into higher education administration. 
Schumaker, P. and Kelly, M. (2012), "Ethics Matter: The Morality and Justice Principles of Elected City Officials and their Impact of Urban Issues." Journal of Urban Affairs, 34: 231-253. Publisher's Official Version available at:

http://dx.doi.org/10.1111/j.1467-9906.2011.00583.x Open Access version: http://kuscholarworks.ku.edu/dspace/.

\section{Ethics Matter: The Morality and Justice Principles of Elected City Officials}

\section{and their Impact on Urban Issues}

A central theme of urban political theory directs attention to the capacity of city officials to enact and implement policies consistent with their autonomous political judgments in the face of many constraints that limit their discretion. On the one hand, mayors, council members, and other local decision-makers have been portrayed as highly constrained prisoners of their environments, especially in theories stressing that policy is more determined by economic factors than political ones (Dye, 1968), that private elites exercise controlling power over community decisions (Hunter, 1953), and that officials have little choice but to pursue their city's unitary interest in economic development (Peterson, 1981). On the other hand, city officials have sometimes been portrayed as having considerable discretion to pursue their own goals, especially in research focusing on their diverse "policy maps" (Eulau and Prewitt, 1974), their roles as political and policy entrepreneurs (Schneider, Teske, and Mintrom, 1995), and their capacity to generate initiatives that push their authority beyond customary roles (Henig and Rich, 2004).

Yet, even when the constraints on officials or the discretion available to them is emphasized, extreme positions on this issue have seldom been embraced. Long ago, James Thompson (1967) argued that the decision-makers of complex organizations such as city governments are constrained by environmental factors, organizational arrangements, and their clients, but that officials often devise strategies for altering these constraints to increase their discretion. A wide range of urban research has indicated that politicians are not merely reactive in the face of constraints, but form political coalitions based on "political logic" to exercise extensive "leverage" over policy decisions (Mollenkopf, 1983: 5-6) and "creative 
Schumaker, P. and Kelly, M. (2012), "Ethics Matter: The Morality and Justice Principles of Elected City Officials and their Impact of Urban Issues." Journal of Urban Affairs, 34: 231-253. Publisher's Official Version available at:

http://dx.doi.org/10.1111/j.1467-9906.2011.00583.x Open Access version: http://kuscholarworks.ku.edu/dspace/.

bounded choice" (Jones and Bachelor (1986: 212). In one influential study, H.V. Savitch and

Paul Kantor (2002: 347) conclude that

"Cities have choices, those choices vary with differential resources, and they are not without constraint. But they are nonetheless choices that can be applied. And most importantly, urban choices are not immutable, but capable of expansion, contradiction, and modification. Or to put the emphasis somewhat differently, cities are not mere leaves in the wind of internationalization, but political entities that in many different ways shape economic outcomes."

Perhaps the study of urban politics is no longer animated by large questions about democratic life - as urbanists retreat unto more narrow policy specializations - but the larger paradigms in the field, as identified by Sapotichne, Jones, and Wolfe (2007: 80-84) have focused on issues of constraint and choice over community decisions.

Pluralism, as developed by Robert Dahl (1961) and his associates, is best understood as a theory about how communities should and do govern themselves democratically, in a manner that reflects their own goals and values. Although pluralists have recognized that the decisions of a democratic community are constrained by capitalist economies, popular concerns, and an elite consensus on the "rules of the game, " they have emphasized that political leaders and subleaders play key roles in city politics and that their choices are instrumental in shaping urban outcomes. Because orthodox pluralists overstated the inclusiveness of democratic processes in community politics, various "neo-pluralisms" were formulated (Waste, 1986) and regime theory was developed, surpassing pluralism as the most cited paradigm guiding the larger questions of power and privilege pursued by urban theorists (Judge, 1995). 
Schumaker, P. and Kelly, M. (2012), "Ethics Matter: The Morality and Justice Principles of Elected City Officials and their Impact of Urban Issues." Journal of Urban Affairs, 34: 231-253. Publisher's Official Version available at:

http://dx.doi.org/10.1111/j.1467-9906.2011.00583.x Open Access version: http://kuscholarworks.ku.edu/dspace/.

Regime theory, as developed by Stephen Elkin (1987), Clarence Stone $(1989,1993)$, and others emphasized that municipal governments may be subject to popular control, but governmental officials develop prevailing coalitions with businesses and other actors that become governing regimes. While corporate or entrepreneurial regimes govern in ways that generally conform to the economic constraints emphasized by Hunter and Peterson, other kinds of regimes exist and can become more prominent. Regime types differ not only in the interests that are included in the governing coalition but on the policy goals that leaders of these regimes articulate and pursue. Regimes can broaden their goals beyond those of promoting business performance (Elkin (1987: 148). According to Stone (1987: 275-281) regimes confront a "spectrum of choices" and adopt policies "based on mixed principles."

Perhaps the third major paradigm in community studies is the collective action theory developed by Elinor Ostrom (1990) and her associates. Also employing regime terminology, she emphasizes that regimes can be obstructive, neutral, or facilitative in their capacity to solve collective action (especially common-pool resource) problems facing various communities. For our purposes, her approach highlights how individual actors are constrained from pursuing their political choices. In democratic communities, no person has the power or the resources to impose his choice on others; they can merely support some options in alliance with others. That does not mean, however, that market forces must dictate community outcomes or that some centralized political authority - a Hobbesian Leviathan - must arise to impose choices on the community. Instead, subtle decentralized forms of political cooperation and power can result in community self-governance. Despite many constraints on collective action, Ostrom's research focuses on how communities can 
Schumaker, P. and Kelly, M. (2012), "Ethics Matter: The Morality and Justice Principles of Elected City Officials and their Impact of Urban Issues." Journal of Urban Affairs, 34: 231-253. Publisher's Official Version available at:

http://dx.doi.org/10.1111/j.1467-9906.2011.00583.x Open Access version: http://kuscholarworks.ku.edu/dspace/.

adopt innovative forms of monitoring and coercion that succeed at solving collective action problems.

While there thus seems to be a broad consensus across the leading paradigms of urban political analysis that urban officials and other political agents have choices in the face of many constraints, our understanding of these choices remains ad hoc and unsystematic. The purposes that motivate public officials to exercise discretion and choice have not been clearly conceptualized. Being "innovative," "strategic," and "maneuvering” (Jones and Bachelor, 1986: 12-13), seeking general policy goals such as educational reform (Henig, et al, 1999), choosing various "social-centered rather than market-centered values" (Savitch and Kanter, 2002: 101-148), and pursuing "community benefits" and the "public good" (Elkin, 1987:150-51) are among the broad motivations that are mentioned in the literature.

We think that behind these various vocabularies is the notion that the authority given to public officials enables them to pursue any of a large number of normative conceptions of what is good for the community and fair to its various citizens. For example, public authorities can be "innovative" and seek to minimize constraints imposed by economic imperatives, existing organizational structures, and traditional political cultures in order to pursue their understanding of good or just outcomes. Public authorities can be "strategic" and engage in "maneuvering" when they design and implement processes and institutions enabling them to better bargain for what they regard as good or just outcomes. Public authorities no doubt pursue "social-centered values," but the question remains as to which such values they give priority. Elkin (1987: 151) is well aware that there is no single conception of "the public good" and that "community benefits" are targeted at some interests and subpopulations more than others. 
Schumaker, P. and Kelly, M. (2012), "Ethics Matter: The Morality and Justice Principles of Elected City Officials and their Impact of Urban Issues." Journal of Urban Affairs, 34: 231-253. Publisher's Official Version available at:

http://dx.doi.org/10.1111/j.1467-9906.2011.00583.x Open Access version: http://kuscholarworks.ku.edu/dspace/.

Thus, the prevailing vocabulary directs attention to officials using their discretion to pursue

what is good for the community and fair to its various citizens, but leaves very vague the content of these choices. Focusing on the specific desired outcomes of particular public officials would, of course, undermine the development of urban theory, so some more general conception of officials'. motivations is required. In this paper we argue that various principles of morality and justice are useful for delineating the normative goals that are pursued by various political actors - and by municipal elected officials in particular.

Such a focus may be regarded as based on an over-idealized conception of urban policymaking. Urbanists normally explain urban outcomes in terms of applications of power on behalf of interests and how constraints affect the power of different interests; such research implies that ethical principles play little role in the real world of city politics. Nevertheless, ordinary understandings of politics acknowledge the centrality of normative ideals. We recognize that political issues typically arise when someone proposes to remedy a bad condition or sees an opportunity to achieve some public good. We observe that many of these ideas are dropped before they get very far because, on balance, they aren't very good ideas, at least in the minds of others whose support is needed. Some question the ability of a policy initiative to advance the specified conception of what is good for the community, while others argue that pursuing the initiative may undermine other community goals. Even if a proposal is thought to be generally good for the community, opposition often arises because it is thought to be unjust, as undermining some conception of fairness. But some proposals survive such evaluations, are pursued, and eventually come to fruition. In this ordinary understanding of urban policymaking, the key factors in explaining outcomes are ethical: adoption of proposals depends on collective determinations of their goodness and their fairness. If actual urban policy making resembles such a portrait, the 
Schumaker, P. and Kelly, M. (2012), "Ethics Matter: The Morality and Justice Principles of Elected City Officials and their Impact of Urban Issues." Journal of Urban Affairs, 34: 231-253. Publisher's Official Version available at:

http://dx.doi.org/10.1111/j.1467-9906.2011.00583.x Open Access version: http://kuscholarworks.ku.edu/dspace/.

ethical principles of policymakers would greatly matter. ${ }^{\mathrm{i}}$ Even if this portrait is idealized, ethical concerns are sometimes likely to be infused into actual urban policymaking processes.

In the first section, we clarify the concepts involved in the issue of the role of constraints and choices in urban policymaking. After a brief discussion of the constraints on policymakers, we offer a conceptualization of the discretionary judgments available to them. The meaning and importance of such related terms as ethics, morality, justice, and ideology are considered. In the second section, we discuss how these terms can be operationalized and measured. While some urbanists complain that ethical judgments cannot be measured and should not be included in scientific analyses of urban politics, ${ }^{\text {ii }}$ we argue the opposite and describe a strategy for studying the role of ethics in urban policymaking. In the third section, we present measures of some of the ethical principles of 95 mayors and council members in twelve cities. We also consider whether measures of the ideological orientations of officials are sufficient to study the norms of these officials, and find that self-defined ideological orientations are far too crude to allow urban analysts to understand the role of normative judgments in policymaking. In the fourth section, we present evidence that officials believe their ethical judgments are often very important in the positions they take and the votes they cast. While showing that collective decisions of city councils are affected by ethical considerations is much more difficult, we provide some preliminary evidence that ethics does indeed matter - at least in the resolution of some important issues.

\section{Constraints and ethical judgments}

How can urbanists more precisely conceptualize the constraints on urban officials and the ethical choices they make? While our primary concern here is with their ethical choices, it is useful to first consider the concept of constraint. Constraints are all contextual factors 
Schumaker, P. and Kelly, M. (2012), "Ethics Matter: The Morality and Justice Principles of Elected City Officials and their Impact of Urban Issues." Journal of Urban Affairs, 34: 231-253. Publisher's Official Version available at:

http://dx.doi.org/10.1111/j.1467-9906.2011.00583.x Open Access version: http://kuscholarworks.ku.edu/dspace/.

that influence decisions. More demanding conceptions of constraints can be offered.

Perhaps constraints should be considered only those contextual conditions that produce unwanted outcomes, ${ }^{\text {ii }}$ but because of the enormous difficulties in accounting for the autonomous preferences of people, iv scholars invariably adopt a less rigorous conception of constraints. Constraints can indeed cause people to act contrary to their desires, but they can also influence what people desire, and they can reinforce actions that are consistent with what people might desire independent of contextual influences. Thus, while the urban literature discusses how economic conditions constrain the choices of officials, making it unlikely that they will act against the economic interests of their communities, it must be recognized that some and perhaps most officials (and other actors) want - or have been influenced to want - the very outcomes that the constraints are said to produce. Perhaps constraints could also be understood as deterministic; if so, a specified contextual factor would have to produce the same decision among all actors, regardless of other contextual conditions and the ethical concerns of officials, to be considered a constraint. Such determinism has little plausibility (Mele, 2009) and, because it undermines concerns about holding people responsible for their choices, it has little attraction (Berlin, 1954; MacIntyre, 1999).

Many contextual factors meet our weak requirements for being considered constraints, but urbanists have focused on economic ones involving limited resources, material needs, and monetary wants. Officials may reject enacting a program they (or others) want because they are influenced by a lack of revenue or a low tax base. Officials may develop policies to attract businesses that provide jobs because they are influenced by a (perceived) need to improve local employment opportunities. Officials may reduce 
Schumaker, P. and Kelly, M. (2012), "Ethics Matter: The Morality and Justice Principles of Elected City Officials and their Impact of Urban Issues." Journal of Urban Affairs, 34: 231-253. Publisher's Official Version available at:

http://dx.doi.org/10.1111/j.1467-9906.2011.00583.x Open Access version: http://kuscholarworks.ku.edu/dspace/.

regulations on market-based activity because they calculate that such regulations will reduce the overall economic prosperity that they (or others) want. There are thus a wide variety of economic constraints, and it may be useful for urban researchers to distinguish clearly among them. ${ }^{v}$ But for present purposes, it is enough to understand that such constraints are neither deterministic nor easily separated from the perceived needs and wants of people. Officials feel constrained by economic considerations because they (or others) want more revenues, jobs, and prosperity. Or at least they want these things more than they want other things that compete with the provision of these material goods.

Urban officials are obviously influenced by many political considerations. Public preferences (both as loosely perceived and as measured by many survey strategies), interest group pressures, and the expectations of various kinds of social and economic elites are among the many political factors that officials feel constrain their choices. But like economic constraints, political ones are neither deterministic nor easily separated from perceived needs and wants of people. Officials can choose not to cave into public preferences, group interests, or elite expectations, but they frequently cater to such political concerns for many reasons - including their own desires to increase their network of political allies and to win elections.

Urban officials are also constrained by the limits of their powers within the municipal governments they lead and the limits of the powers of these municipal governments in relationship to other governmental actors in the larger federal and legal systems in which they operate. Officials may feel constrained by their need to retain collegial relations with other council members and thus decide against pressing their judgments on matters where their peers are thought to have more expertise or more pressing interests. They may feel 
Schumaker, P. and Kelly, M. (2012), "Ethics Matter: The Morality and Justice Principles of Elected City Officials and their Impact of Urban Issues." Journal of Urban Affairs, 34: 231-253. Publisher's Official Version available at:

http://dx.doi.org/10.1111/j.1467-9906.2011.00583.x Open Access version: http://kuscholarworks.ku.edu/dspace/.

constrained by the overall organizational structure of the municipal government in which

they operate. They may be told that their state government has not granted them jurisdiction

to act as they want. Or they may fear that a court will over-ride their decision. There are many such possibilities, but like economic and political constraints, they are subject to interpretation, and officials can always choose to act in ways that belie these constraints, especially if they feel a strong ethical compulsion to do so.

Most generally, ethics are normative considerations about how one ought to choose and act. Laura Stoker (1992: 370) provides a useful conception of ethics:

"Judgments expressed in the evaluative language of ethics as to what is 'good' or 'right' lay claim to what we should value or what one should value, resting upon interpersonal justifications that we can (and often do) disagree about."

So understood, ethics is the broadest and most inclusive conception of human normative judgment. Like most other contemporary ethical theorists, Stoker stresses ethical pluralism, recognizing that ethics involve diverse values, evaluative disagreement, and the need to justify to others the values one pursues. Ethical pluralists recognize that people are confronted by "incommensurable choices" because there is no common standard or ordering of values by which choices can be objectively evaluated (Madsen and Strong, 2003: 4). Thus, people generally and public officials in particular express and justify diverse normative principles that they claim guide their decisions. ${ }^{\mathrm{vi}}$ The legitimacy of their actions depends on others accepting or at least acknowledging the reasonableness of these justifications (Gutmann and Thompson, 2004: 3-4).

Ethics includes a variety of principles about how people should act to remain true to themselves, to live good personal lives, and to forge strong and fair interrelationships with 
Schumaker, P. and Kelly, M. (2012), "Ethics Matter: The Morality and Justice Principles of Elected City Officials and their Impact of Urban Issues." Journal of Urban Affairs, 34: 231-253. Publisher's Official Version available at:

http://dx.doi.org/10.1111/j.1467-9906.2011.00583.x Open Access version: http://kuscholarworks.ku.edu/dspace/.

others. No doubt these elements of ethics have political relevance, but we wish to focus on the two dimensions of ethics that are most important to urban elected officials in their roles as policymakers: political morality and political justice.

Political morality concerns various conceptions of what is generally good for the political community. Although the term "the common good" is often used to convey such moral concerns, it can be misleading in at least two ways. First, it can be understood to imply that there is one unitary conception of what is good for the community, but such an understanding is highly problematic. People bring various abstract conceptions of "the common good" to political issues, and even if they agree on what it means abstractly, they often reach different judgments about which policy alternative is consistent with it.vii Second, what is generally good for a political community is seldom something that is a common good. Something can be generally good for the political community because it is good for most current citizens, or it is good for the collectivity, or it serves the long-term interests of most people and the community, but still be harmful to some people, or some aspects of community life both in the present and the future. Because of the way individuals are differentially impacted by what is generally good for the community, the utilitarian concept of "the greater good for the greater number" is often used to convey that "the public interest" is not the same as the common good (Held, 1970). We shall see, however, that the utilitarian principle provides but one conception of political morality.

Political justice concerns various conceptions of what constitutes a fair distribution of the benefits and burdens among individuals and groups that result from policy decisions. It is an element of broader ethical concerns about fair dealings and fair outcomes. Even while public officials can be oblivious to fairness in the interpersonal relationships of people or 
Schumaker, P. and Kelly, M. (2012), "Ethics Matter: The Morality and Justice Principles of Elected City Officials and their Impact of Urban Issues." Journal of Urban Affairs, 34: 231-253. Publisher's Official Version available at:

http://dx.doi.org/10.1111/j.1467-9906.2011.00583.x Open Access version: http://kuscholarworks.ku.edu/dspace/.

unconcerned about the "social justice" of the overall distribution of social goods that are generated by broader social structures (particularly by a capitalist economy) they can and do have normative concerns about how various people are affected by their political decisions. Believing that people should be equally effected, that those with the greatest needs should most benefit, and that the most deserving should get the lion's share of public benefits are among the many conceptions of fair distribution that public officials can bring to their policy choices.

It is sometimes thought that the different ideological orientations of officials convey their different normative judgments about political morality and political justice. In popular discourse, contemporary conservatives are said to value economic productivity and growth more than social programs that benefit the needy, while contemporary liberals are said to have the opposite normative priorities. While such understandings are not entirely misguided, ideological differences do not adequately convey the morality and justice principles of officials. Rigorously understood, ideologies convey many things beyond people's commitments to what is good for the community and what is fair to people within it. Included within a well-developed ideology is a set of beliefs about how political communities actually work as well as how they should work. Included within a well-developed ideology are many ontological, psychological, sociological, and epistemological assumptions as well as political principles on matters like citizenship and authority that are distinct from conceptions of how the common good and justice should guide policy (Schumaker, 2008). Given the complexity of what is included within ideological designations, few people hold well-developed ideologies or have extensive ideological consistency in their normative values. Even politicians who embrace an ideological label or are regarded by others as having an ideological orientation 
Schumaker, P. and Kelly, M. (2012), "Ethics Matter: The Morality and Justice Principles of Elected City Officials and their Impact of Urban Issues." Journal of Urban Affairs, 34: 231-253. Publisher's Official Version available at:

http://dx.doi.org/10.1111/j.1467-9906.2011.00583.x Open Access version: http://kuscholarworks.ku.edu/dspace/.

can have, and often do have, different principles of political morality and justice, because their commitments to liberalism or conservatism (or other ideological perspectives) are based on other elements of ideologies than such principles. Additionally, ideologies are usually regarded as being "rigid," providing set principles that ideologues apply to each and every decision, but, in practice, people frequently apply different conceptions of political morality and justice to different issues within different contexts (Walzer, 1983; Scott and Bornstein, 2009). In short, the morality and justice principles that officials hold and apply are inadequately captured by their ideological orientations - whether these be attributions or self-definitions.

In summary, while urban policymaking is subject to many contextual constraints, there is room for officials to exercise many ethical choices. While many languages can be used to express and justify these choices, political and urban theory about these choices is most likely to be advanced by realizing that the different choices that officials make are aimed at securing various conceptions of the good of the community and justice to individuals within the community. ${ }^{\text {viii }}$ While leading paradigms of urban politics recognize the role of ethics in the choices made by city officials, they have yet to develop a framework beyond the inadequate measures of officials' ideological orientations for specifying the morality and justice principles involved. Urban analysts need ways of measuring the support of officials for diverse ethical principles, and the can profit from systematic studies of when and why various principles come into conflict, of how officials resolve these conflicts, and the conditions when various principles are likely to affect policy decisions. This paper begins to explore such concerns. 
Schumaker, P. and Kelly, M. (2012), "Ethics Matter: The Morality and Justice Principles of Elected City Officials and their Impact of Urban Issues." Journal of Urban Affairs, 34: 231-253. Publisher's Official Version available at:

http://dx.doi.org/10.1111/j.1467-9906.2011.00583.x Open Access version: http://kuscholarworks.ku.edu/dspace/.

\section{A new study of the role of elected officials in urban policymaking}

For this exploratory study, we completed 95 interviews with mayors and council members in 12 cities in two regions and three states. Table 1 lists these cities and shows their considerable social, economic, and political differences. Eight cities in the Kansas City metropolitan area provided a convenient location to begin these explorations. Kansas City, Missouri (KCMO) and Kansas City, Kansas (KCK) were included as core central cities that have extensive minority populations and that pursued different revitalization strategies during the time period of this study. KCMO achieved over $\$ 6$ billion in major downtown redevelopments during the first decade of the $21^{\text {st }}$ century, while KCK developed a new 400 acre entertainment and retail complex on that city's western edge. Overland Park was selected as the largest and most prosperous suburb; for many years it was the only major Kansas community having partisan elections, but to reduce the role of partisanship in local politics, it adopted nonpartisan elections in 2001. Lee's Summit was selected as a fastgrowing and prosperous city, but one having a more traditional culture than Overland Park. Raytown is a smaller suburb on KCMO's eastern border that thrived as a "white flight" community during the 1950 's and 60 's, but in recent years, it has seen an influx of minorities and lower-income citizens, and has experienced economic decline. St. Joseph was included because it was once one of Missouri's largest cities and one noted for its individualist culture, but it has experienced significant population losses and economic decline in recent decades. Topeka, 50 miles to the west of Kansas City, was chosen as a government city, the State Capitol. The 1954 Supreme Court ruling in Brown vs. Board of Education of Topeka did not end its struggles with discrimination; while the city is now over 20 percent nonwhite, most blacks and Hispanics live on the east side of this conservative community. Lawrence, located 
Schumaker, P. and Kelly, M. (2012), "Ethics Matter: The Morality and Justice Principles of Elected City Officials and their Impact of Urban Issues." Journal of Urban Affairs, 34: 231-253. Publisher's Official Version available at:

http://dx.doi.org/10.1111/j.1467-9906.2011.00583.x Open Access version: http://kuscholarworks.ku.edu/dspace/.

between Kansas City and Topeka, was chosen because of its reputation as a liberal university town. While conservatives have dominated city government, a majority of city commissioners identified with a progressive coalition during the 2003-07 period.

- Table 1 goes here -

In order to provide a basis for considering whether the findings from the Kansas City area might extend beyond America's heartland, we also studied four cities in California, though not in the same depth as the KC metro area. Berkeley was selected because of its history of leftist politics and having progressive city government (Clavel, 1986: 96-138). Richmond, to the north of Berkeley in the East Bay, was selected because of its extensive minority population, as 36 of its citizens are Hispanic and another 25 percent are Black. Its minorities were partially incorporated into a biracial governing coalition 30 years (Browning, Marshall, and Tabb, 1983: 259-60) and are now better represented in city government. It currently has a Green Party mayor. Stockton was selected as the largest city in California's Central Valley; although racially mixed and reasonably diverse economically, it has been slow to achieve minority incorporation (Browning, Marshall, and Tabb, 1983: 260) and has been dubbed "America's most miserable city" by Forbes Magazine in 2011, largely owing to its steep decline in housing values. Lodi is a smaller city in the Central Valley and its politics has generally been regarded as economically and socially conservative.

Despite the diversity of these cities, we do not, of course, claim that they constitute a random sample. Consequently, this paper presents mostly descriptive data providing overall findings based on these cities, although we occasionally describe specific cities. Such findings are meant only to illustrate theoretical concerns. Much more extensive research in 
Schumaker, P. and Kelly, M. (2012), "Ethics Matter: The Morality and Justice Principles of Elected City Officials and their Impact of Urban Issues." Journal of Urban Affairs, 34: 231-253. Publisher's Official Version available at:

http://dx.doi.org/10.1111/j.1467-9906.2011.00583.x Open Access version: http://kuscholarworks.ku.edu/dspace/.

representative cities throughout the US and elsewhere will be required to develop and test theories of how ethics matter in urban politics.

Between 2003 and 2007 we contacted incumbent current mayors and council members in these cities, asking them to participate in extensive two-stage interviews. ${ }^{i x}$ All but two mayors agreed to participate, and the participation rate of council members was also high, ranging from 62 percent in Berkeley to 100 percent in Lee's Summit. During these interviews, we attained information on many factors that social scientists usually examine to explain the policymaking behavior of urban officials, but we discuss here only those portions that provided the data reported below.

During the first interview, we presented officials with a lengthy list of principles of morality and justice, prefacing our queries with the comment that political philosophers and commentators often referred to such principles when discussing and analyzing policy decisions, that there was often widespread disagreement among thoughtful people on the meaning, importance, and applicability of these principles, and that we were interested in their allegiance or opposition to them. We asked officials to begin by providing a preliminary reaction to each principle using a 5-point scale, ranging from strong opposition (1) to strong support (5). We then probed the meanings they gave to each principle, their reasons for opposing or supporting each one, the sort of issues that arise on the council where these principles seem applicable, and if there might be circumstances that could prompt them to abandon their expressed position on a principle. In light of these discussions, we sometimes suggested revisions of officials' initial scores. The measures that were ultimately assigned and reported below are based on officials' considered assessments of their support for each principle. 
Schumaker, P. and Kelly, M. (2012), "Ethics Matter: The Morality and Justice Principles of Elected City Officials and their Impact of Urban Issues." Journal of Urban Affairs, 34: 231-253. Publisher's Official Version available at:

http://dx.doi.org/10.1111/j.1467-9906.2011.00583.x Open Access version: http://kuscholarworks.ku.edu/dspace/.

During the first interview, we also asked each official to identify and provide basic information on what he or she regarded as "the most controversial and/or significant" issues that had arisen recently or were under consideration at that time. After completing the firstround of interviews in a city, we determined which issues had been most frequently mentioned and had been at least partially resolved (i.e., there had been at least some council votes on the matter). We then proceeded to the second round of interviews that focused on these concrete issues. For each issue selected for study, we asked officials how they had voted and to explain, in their own words, the basis of their preferences and votes. Drawing on a technique pioneered by John Kingdon (1989), we followed up on their responses by going through a checklist of factors that might have played a role in the positions they took. Did group pressures influence their positions? Did public opinion? The views of other officials? Legal considerations? Jurisdictional considerations? The local political culture? How important were economic considerations? How important were their own principles of morality and justice? After brief discussions of these factors, we asked officials to score the importance of each in determining their voting behavior on the issue, using an ordinal scale that ranged from being irrelevant $(0)$ to being the consideration of most importance to them (5). We also asked officials to discuss the morality and justice principles that concerned them on these issues.

Table 2 shows considerable community and state-level differences in the extent to which officials claimed that their policy decisions were based on their principles of morality and justice. Berkeley officials stressed that their ethical concerns were very important, while Overland Park officials generally assigned such concerns a minor role. Overall, compared to city officials in Missouri and Kansas, those in California emphasized the importance of ethics 
Schumaker, P. and Kelly, M. (2012), "Ethics Matter: The Morality and Justice Principles of Elected City Officials and their Impact of Urban Issues." Journal of Urban Affairs, 34: 231-253. Publisher's Official Version available at:

http://dx.doi.org/10.1111/j.1467-9906.2011.00583.x Open Access version: http://kuscholarworks.ku.edu/dspace/.

in urban policy making. Because the descriptive data reported in the next section are derived primarily from city officials from Missouri and Kansas, the validity our thesis that ethics matter may be underestimated.

\section{Support among 95 City Officials for Various Morality and Justice Principles}

To map the ethical concerns of urban elected officials, we presented our interviewees with an extensive list of principles of morality and justice that are widely cited by political actors, invoked by commentators, and discussed in the scholarly literature. Some of these principles are very complex and have been rigorously expressed in arcane, scholarly languages, and so we tried to articulate the underlying ethical concerns as simply and clearly as possible, giving each principle a name that we hoped would help provide common meanings. We report the average levels of support and variations in support for various principles of morality among our 95 elected officials in Table 3, and their support for various principles of justice is reported in Table 4 .

Contemporary scholars working in the fields of moral philosophy, justice, and a reconstructed political pluralism doubt that there is one ethical principle - or even a few such principles - that is so important that it should guide the choices and actions of all people in all circumstances. Instead, they recognize that people have allegiances to a large and expanding universe of ethical principles. This "pluralism" was evident among most of the officials that we interviewed. They sometimes took exception to the way we had articulated various principles and thought that their related ethnical concerns could be better expressed in other ways. ${ }^{\mathrm{x}}$ They usually expressed some ambivalence about various principles and avoided the "strongly supportive" or "strongly opposed" options, as they could see occasions when various principles should be applied and other occasions when the application of a principle should be problematic, in part because 
Schumaker, P. and Kelly, M. (2012), "Ethics Matter: The Morality and Justice Principles of Elected City Officials and their Impact

doing so would conflict with other ethical concerns that they held. And, of course, there was some - and sometimes considerable - ethical disagreement among officials.

- Tables 3 and 4 go here -

Table 3 reveals extensive variation in the overall support for various morality principles, and that specific morality principles are subject to moral disagreement. Most supported is the idea that officials should promote good citizenship, a finding that Michael Sandel would find odd though perhaps encouraging. According to Sandel (1996: 321-24), the most important common good of a democratic republic is achieved when citizens have "character of mind, " "habits of the heart," and various other aspects of being engaged in community politics in a public-regarding rather than narrowly self-regarding manner. However, he argues that the last century has witnessed a turn away from "the formative project" of instilling such virtues. While encouraging good citizenship was central to early republican theorists and political leaders, the "liberal" theorists and leaders that dominate today's politics - even when they focus on the local level where citizenship can best be developed and expressed - now emphasize the other two broad ethical concerns discussed in this paper: political morality and political justice. Such ethical concerns can be brought to politics by political leaders, even if citizens do not actively pursue them. In short, for communitarians like Sandel, this principle is very different from the other principles of morality listed in Table 3. The other principles state what public officials should do for the good of community members. While we framed our expression of the good citizenship principle as a norm that officials might encourage, it is ultimately about what citizens can and should do for themselves if they are to be self-governed. While the extensive support given this principle by officials suggests that Sandel has exaggerated the extent to which republican 
Schumaker, P. and Kelly, M. (2012), "Ethics Matter: The Morality and Justice Principles of Elected City Officials and their Impact

norms have been forgotten, it is also possible that giving lip-service to good citizenship is deeply inculcated in public officials, even though they seldom give much thought to how their policy decisions affect citizenship. Since our officials seldom referred to this principle when justifying their policy decisions, we simply note the discrepancy between holding and acting upon good citizenship principles, and turn our attention to the other ethical principles listed in Tables 3 and 4.

We introduced officials to utilitarianism by formulating this principle in a manner that draws attention to the ethical limitations of the individualistic (or liberal) conception of the common good - that it involves maximizing the sum total of satisfactions of the diverse individuals within a community, regardless of the fairness of how these satisfactions are distributed. While officials were generally supportive of basing decisions on "the greater good of the greater number," they usually hesitated when we added the complaint of Rawls (1999) that this involves overlooking any unfair distributions that this entails. Given this stricture, many officials abandoned strong support for utilitarianism, and instead claimed to modestly support this principle or to have mixed feeling about it.

The next four principles listed address competing conceptions of the resolution of issues about liberty and privacy. Typically, urban officials modestly support "practicing neutrality;" they think they should avoid limiting citizens from freely pursuing their own conceptions of the good life when their private choices do not harm others, such as concerning consensual sexuality. In this, they seem to accept John Stuart Mill's (1859) insistence that such individual freedom is consistent with a utilitarian conception of maximizing human happiness and well-being. They are particularly wary of restricting individual freedom by passing restrictions that require citizens to adhere to dominant 
Schumaker, P. and Kelly, M. (2012), "Ethics Matter: The Morality and Justice Principles of Elected City Officials and their Impact of Urban Issues." Journal of Urban Affairs, 34: 231-253. Publisher's Official Version available at:

http://dx.doi.org/10.1111/j.1467-9906.2011.00583.x Open Access version: http://kuscholarworks.ku.edu/dspace/.

religious beliefs. Their support for practicing neutrality is more often diminished by the thought that they should pass laws that reflect traditional values that are dominant locally. While most officials had mixed feeling about this principle, some thought that it's application would violate individual freedoms and others thought that reflecting traditional local values on at least some issues would benefit the community and thus should take precedence over individual freedom. Regulating land use was one such area. For most officials, some uses of private property undermine public purposes in ways that justify some restrictions on the freedoms that citizens have to use their property as they wish.

The final seven principles listed in Table 3 deal more directly with economic principles of morality, which some regard as an oxymoron. In this view, public officials pursue economic development and growth at the expense of moral values, not in pursuit of them. But if principles of morality deal with what is generally good for the community, and if economic development enhances overall material prosperity, job opportunities, and other widely sought economic benefits, then it is appropriate to regard various economic principles as ones of morality. As Benjamin Friedman (2005: 3-17) points out, greater community affluence has many advantages, including facilitating more "opportunities, tolerance, mobility, fairness, and democracy," but the advantages of economic prosperity are "mostly in the material realm, and we have always been reluctant to advance material concerns to the highest plane in our value system." We are warned that economic growth threatens our spiritual life and a sustainable environment, and more economic development always changes community life in ways that are viewed, at least by some, as undesirable. Nevertheless, Friedman correctly insists that modern Western polities have developed a "moral presumption in favor of precisely those aspects of personal behavior that lead to greater productivity and economic growth." 
Schumaker, P. and Kelly, M. (2012), "Ethics Matter: The Morality and Justice Principles of Elected City Officials and their Impact of Urban Issues." Journal of Urban Affairs, 34: 231-253. Publisher's Official Version available at:

http://dx.doi.org/10.1111/j.1467-9906.2011.00583.x Open Access version: http://kuscholarworks.ku.edu/dspace/.

Granting that income and wealth is highly valued while recognizing that the pursuit of economic prosperity often has social costs, we articulated a general morality principle that addresses the priority that officials should give to economic growth, even at the expense of other social goals. When phrased this way, only 10 of our officials said that they strongly supported promoting economic growth, while only three said they were strongly opposed to promoting growth. Most officials claim to be weak supporters of this principle and to having mixed feeling about it.

Whatever officials' general attitudes about economic growth, they need more specific moral principles about their roles in pursuit of it. Officials are fairly divided on whether the free market should be the key vehicle for generating economic growth or if government should intervene in market choices. They are divided about their role in subsidizing new businesses that promise to bring more job opportunities and wealth to their community. They are much more supportive of the notion that city governments do have a role in providing public goods, but there are different levels of support for different kinds of public goods. Most important for officials is improving the physical infrastructure (the roads, bridges, sewers, and so forth) that involve the kind of long-term investments upon which all communities depend. Almost as important is improving day-to-day public services (police and fire protection, trash collection, and so forth) that all citizens need at some level. Important, but less so, are amenities (such things as parks, sports facilities, and museums) that add to the quality of life but perhaps are less essential than basic infrastructure and public services. While most officials quickly acknowledged that keeping taxes low serves the economic interests of the community, only a minority supported cutting taxes if that means neglecting public infrastructures, reducing services, and cut-backs on amenities. 
Schumaker, P. and Kelly, M. (2012), "Ethics Matter: The Morality and Justice Principles of Elected City Officials and their Impact of Urban Issues." Journal of Urban Affairs, 34: 231-253. Publisher's Official Version available at:

http://dx.doi.org/10.1111/j.1467-9906.2011.00583.x Open Access version: http://kuscholarworks.ku.edu/dspace/.

The normative judgments that officials must make about the fairness of their decisions are as numerous and daunting as their judgments about what is good for the community. Most officials doubt that it is their duty to distribute city resources and services equally, because they believe that some things should be distributed primarily to the most needy citizens while other things should to be distributed to the most deserving. If there is an ethical consensus among officials, it is that they and their governments should not discriminate and indeed should pass and enforce laws that prohibit racial, gender, and other such forms of discrimination. But the principle of "combating bias" does not translate immediately into support for pursuing equal opportunity. While most officials do support the norm that minorities, women, and other such groups be able to complete fairly, 18 percent worried that some equal opportunity programs went too far, creating "reverse discrimination." While only 12 percent claimed to support quotas, over half of our officials said that they supported giving consideration to race and other such social characteristics in order to promote social diversity.

When officials reject equality as an adequate conception of political justice, they usually do so because they think that officials have an ethical responsibility to help those that Rawls calls "the least advantaged" - people whose natural talents, social backgrounds, and current economic circumstances leave them in need of public assistance. To simplify the wellknown but complicated "difference principle" of Rawls (1999: 52-72), we asked officials if they thought they should "focus on the least-well off," adopting policies that improve their condition and avoiding policies that harmed them. While there was considerable support for this principle, most officials thought it was too all-embracing. Even though supportive of some policies that benefit the poor, some officials did not think the poor deserved some sort 
Schumaker, P. and Kelly, M. (2012), "Ethics Matter: The Morality and Justice Principles of Elected City Officials and their Impact of Urban Issues." Journal of Urban Affairs, 34: 231-253. Publisher's Official Version available at:

http://dx.doi.org/10.1111/j.1467-9906.2011.00583.x Open Access version: http://kuscholarworks.ku.edu/dspace/.

of "veto" over any policy initiative that might adversely affect them. Thus, there was somewhat more support for two other principles of justice on behalf of the needy. One such principle is that everyone has a human right to basic welfare, that each member of the community is a rights-holder and can make legal claims on government to provide those social goods and services needed for an adequate standard of living when they lack the resources to pay for them (Nickel: 2007: 137-142). While urban officials are sympathetic to such welfare rights, only 27 percent strongly support the idea as articulated in Table 4 . Reluctance to more strongly embrace welfare rights comes not only from moral objections to the welfare state but also from the concern of urban officials that welfare rights entail specific legal guarantees that should be provided by national and state governments, but not local ones. ${ }^{x i}$ Some officials preferred a related but distinct principle: that local officials should support and fund programs providing socially-recognized needs; Rawls (1999: 244) calls these programs "social minimums," but we adopted the language of Frohlich and Oppenheimer (1992: 36) and labeled this the "floors principle." While welfare rights imply a legal duty, providing floors involves only an ethical duty. When guided by the floors principle, social service providers determine the kinds of social goods to be made available to the needy and the "floor" or minimal allotments of such goods below which no citizen should sink. The floors principle invites political leaders to allocate public funds based on ethical understandings within the community. The needy can apply for public assistance to meet their minimal needs, but they lack any rights claims as to what they might receive. The floors principle thus makes looser demands on officials than that of welfare rights, leading to considerable "mixed feelings" about it, especially by those officials who have strong concerns about having local government provide public assistance for the needy. Because most officials 
Schumaker, P. and Kelly, M. (2012), "Ethics Matter: The Morality and Justice Principles of Elected City Officials and their Impact of Urban Issues." Journal of Urban Affairs, 34: 231-253. Publisher's Official Version available at:

http://dx.doi.org/10.1111/j.1467-9906.2011.00583.x Open Access version: http://kuscholarworks.ku.edu/dspace/.

have ethical concerns about helping the needy, they tend to reject the libertarian norm of avoiding redistribution (see Nozick, 1974).

The next five principles of justice address various canons of just desert (Rescher, 1982: 73-83; Sher, 1987). While need-based justice principles are redistributive, involving transfers of social goods from the more well-off to the less well-off, desert-based principles may accentuate existing inequalities. For this reason, urban officials tend to be more opposed than supportive of them. If assisting those with natural disabilities is redistributive, then rewarding those with the most natural talent is regarded as having the opposite effect. While officials see some occasions for following this principle - as when they provide a hefty salary increase to a highly talented city manager because they believe her talents serve the city well - they often assert that cities are not generally in the business of rewarding the talented. They are a bit more predisposed to reward people according to their social and market contributions, but overall, there is more opposition than support for such principles, as public officials think that such contributions have their own rewards or that other organizations than city governments should recognize such merit. The most supported precept of just desert is that effort should be rewarded, as some officials claim that city government should "help those individuals or neighborhood groups that help themselves." The least supported precept of just desert is that those making greater tax contributions should receive more policy benefits. Even those officials who claim that the redistribution of wealth should be avoided nevertheless usually recognize that the well-off should pay higher taxes to pay for public goods, without expecting to receive special treatment.

The many principles of morality and justice available to officials (and citizens generally) may prompt analysts to adopt or seek two simplifications. Rather than probe the 
Schumaker, P. and Kelly, M. (2012), "Ethics Matter: The Morality and Justice Principles of Elected City Officials and their Impact of Urban Issues." Journal of Urban Affairs, 34: 231-253. Publisher's Official Version available at:

http://dx.doi.org/10.1111/j.1467-9906.2011.00583.x Open Access version: http://kuscholarworks.ku.edu/dspace/.

degree of allegiance people have to diverse ethical principles, they often assume that measures of ideological orientations are adequate surrogate measures of ethical orientations. Or, having measured allegiance to diverse principles, they may be tempted to locate the underlying dimensions of ethical orientations by using such statistical techniques as factor analysis. We believe that the first strategy is mistaken, and the second is misguided.

As argued in section 1, ideological orientations are very crude indicators of the ethical principles of people, including elected officials. The last column in Tables 3 and 4 provide evidence of this. During our interviews, we asked officials to indicate their ideological orientations on a 5-point scale (from strongly conservative to strongly liberal), and we correlated their support for various ethical principles with this measure. While many ethical principles are moderately related to self-defined ideological orientations, none are strongly related. The more conservative is an official's ideological orientation, the more he or she is likely to hold the principles of practicing laissez-faire, avoiding redistribution, reflecting local cultural and dominant religious beliefs, minimizing taxation, applying utilitarianism, and promoting economic growth. The more liberal is an official's ideological orientation, the more he or she is likely to hold principles of enhancing diversity, investing in amenities, improving public services, providing floors, and focusing on the least well-off. But these modest correlation coefficients mean that self-defined ideological orientations are not very indicative of officials' allegiance to principles that are commonly regarded as central to contemporary liberalism or conservatism. To get a sense of how often ideological attributions of ethical stances would be misguided, consider the two principles most strongly correlated with ideology. Only $36 \%$ of the officials who saw themselves as strong conservatives were strongly supportive of practicing laissez-faire, while $15 \%$ of the strong liberals were also strongly supportive of laissez-faire. Only $46 \%$ of the strong liberals in our study were 
Schumaker, P. and Kelly, M. (2012), "Ethics Matter: The Morality and Justice Principles of Elected City Officials and their Impact of Urban Issues." Journal of Urban Affairs, 34: 231-253. Publisher's Official Version available at:

http://dx.doi.org/10.1111/j.1467-9906.2011.00583.x Open Access version: http://kuscholarworks.ku.edu/dspace/.

strong supporters of enhancing diversity, while nine percent of our strong conservatives also were strong supporters of diversity. Beyond resulting in such extensive misrepresentation of allegiance to these principles, knowing the self-defined ideological orientation of public officials would give analysts almost no purchase on several ethical principles like regulating land use, subsidizing new business, and combating bias that are normally regarded as ideologically divisive and central to urban politics. In short, if analysts were to find significant linkages between officials' ideological orientations and their policy positions, they would be poorly positioned to make inferences about the ethical principles that prompt either conservatives or liberals to adopt their policy positions.

Another way to understand the limitations of using ideological orientations as indicators of ethical ones is to consider the most basic conclusion that could be drawn from our study. Our measures of the ideological orientations of officials show a slight tilt to the right. Of our 95 officials, 29 claimed to be moderate or strong conservatives while 26 claimed to be moderate or strong liberals (the other 38 percent claimed to be "in the middle of the road"). Yet, there is, overall, considerably more support among officials for principles associated with contemporary liberalism (e.g., practicing neutrality, regulating land use, and focusing on the least well-off) than for those associated with contemporary conservatism (e.g., reflecting dominant religious beliefs, avoiding redistribution, and minimizing taxes). As a brand name, liberalism is relatively disparaged, even while there is extensive support for liberal ethical principles. Studies that use ideological attributions are likely to mischaracterize the overall trajectory of city politics.

The other simplification approach would also be unfortunate. Perhaps factor analysis, cluster analysis, or some other dimension reduction technique would show sufficient intercorrelations among, for example, our need-based principles of justice or our precepts of just 
Schumaker, P. and Kelly, M. (2012), "Ethics Matter: The Morality and Justice Principles of Elected City Officials and their Impact of Urban Issues." Journal of Urban Affairs, 34: 231-253. Publisher's Official Version available at:

http://dx.doi.org/10.1111/j.1467-9906.2011.00583.x Open Access version: http://kuscholarworks.ku.edu/dspace/.

deserts to prompt analysts to generate single indices of such ethical dimensions, but the gains in simplicity would be outweighed by the substantive and theoretical losses. Substantively, urban officials do differentiate between different need-based principles - or some do at least some of the time. When deciding on funding social services, justifications based on welfare rights principles are off-putting to some officials in ways that justifications based on floors principles are not. Theoretically, ethical theorists increasingly stress the complexity of ethical judgments. Theories like those of Rawls and Nozick that sought to reduce justice to a few principles have been superceded by a reconstructed pluralist approach that recognizes that related ideas like Rawls' difference principle and the floors principle are sufficiently different in meaning and application that they each have roles in the ethical judgments of people and in developing an ethical society.

\section{The Impact of Ethical Principles on the Policy Decisions of Urban Officials}

Our most basic hypothesis is that city officials draw upon their ethical principles when making policy decisions - at least more often than suggested by most urban theory. At the beginning of our exploration of the role of ethics in urban policymaking, we had no firm basis for specifying the extent to which ethics matter or the conditions when ethical matters are most important, and so we employed an inductive approach to assess the importance that officials attributed to their own ethical concerns relative to other considerations stressed in the urban politics literature. In all, we explored between 7 and 9 issues in each of our 12 cities, resulting in a total of 93 issues. Between 4 and 12 officials provided their assessments on these issues, resulting in a total of 655 cases where we attained measures of officials' assessments of the importance of various considerations in forming their stances on these issues. The "all cases" column in Table 5 shows the overall results. 
Schumaker, P. and Kelly, M. (2012), "Ethics Matter: The Morality and Justice Principles of Elected City Officials and their Impact of Urban Issues." Journal of Urban Affairs, 34: 231-253. Publisher's Official Version available at:

http://dx.doi.org/10.1111/j.1467-9906.2011.00583.x Open Access version: http://kuscholarworks.ku.edu/dspace/.

In general, officials claim that their own ethical principles rival economic concerns as the most important bases of their policymaking behavior. They claim that group pressures and citizen preferences are of minor or secondary importance, as they report that on many issues there simply is little group involvement or that group pressures tend to cancel each other out, and that few citizens are aware of these issues or express their policy views. Other considerations like being persuaded by other officials, being constrained by legal and jurisdictional concerns, and not straying too far from local cultural values were also cited, but overall, these considerations were even less important than group demands and citizen preferences - and far less important than economic and ethical concerns.

To investigate whether ethical concerns are more important on some policy issues than others, we first draw upon the work of Peterson (1981), Lowi (1964), and others who have stressed that the determinants of policy decisions vary across policy domains. Our issues fall into five main domains or categories: public provision, economic development, public assistance, economic regulation, and social regulation.xii The category of "public provision" captures the sort of issues that Peterson (1981: 150-166) labels as "allocational," but while he stresses more routine "housekeeping" issues, we include more controversial budget issues involving possible expansions and cuts and significant changes in the delivery of city facilities and services. Our economic development category mirrors that of Peterson (1981: 131-149), focusing on public support for private developments (especially new industrial and commercial enterprises) and redevelopments (especially downtown projects) that are thought to "contribute to the economic well-being of the city." The category "public assistance" corresponds to the "redistribution" category of Peterson (1981: 167-183), but because cities seldom pursue any significant redistribution of income and wealth, our public 
Schumaker, P. and Kelly, M. (2012), "Ethics Matter: The Morality and Justice Principles of Elected City Officials and their Impact of Urban Issues." Journal of Urban Affairs, 34: 231-253. Publisher's Official Version available at:

http://dx.doi.org/10.1111/j.1467-9906.2011.00583.x Open Access version: http://kuscholarworks.ku.edu/dspace/.

assistance category allows us to include any efforts by city officials to respond to the needs of its least advantaged citizens. Missing from Peterson's typology of policy issues are those that Lowi regards as "regulatory," but two major types of regulations concern cities. The "economic regulations" category involves ordinances regarding zoning, building codes, and other uses of land and property. The "social regulations" category involves laws regulating behaviors that some find socially objectionable, even if the harm to others is insignificant or indirect (e.g., consensual sexuality, gambling, smoking, using alcohol and "recreational" drugs, and other "sins" and "vices")

As shown in Table 5, the differences across these categories in the considerations that move public officials are not as great as suggested by domain theory, but some tendencies are suggested.xiii Not surprisingly, economic concerns are important in all domains, but especially so when economic development issues arise. Ethical principles are least important on economic development issues, but they seem more important than any other consideration when public assistance and social regulation issues arise. In this regard it should be noted that officials did not necessarily see economic considerations as weighing against public assistance, as they thought many programs to help the disadvantaged could have significant positive economic impacts. xiv $^{\text {iv }}$

Beyond investigating how the importance of ethics varies across policy domains, we also examined each of our 93 issues to assess the importance of ethics in its resolution and the ethical principles that were cited as most important. Describing these findings in detail is beyond the scope of this paper, but we can suggest some of the major patterns and provide illustrations of them. 
Schumaker, P. and Kelly, M. (2012), "Ethics Matter: The Morality and Justice Principles of Elected City Officials and their Impact of Urban Issues." Journal of Urban Affairs, 34: 231-253. Publisher's Official Version available at:

http://dx.doi.org/10.1111/j.1467-9906.2011.00583.x Open Access version: http://kuscholarworks.ku.edu/dspace/.

About a quarter of our issues were resolved without ethics playing any significant role. ${ }^{\mathrm{xv}}$ The issue that had the lowest overall ethics-matter score involved a series of decisions by the Overland Park City Council to move toward greater privatization in the provision of city services and facilities during the 2003 to 2007 period. Such privatization did not involve any service cutbacks but rather took the form of contracting out such work as engineering new public works projects, hiring private firms to take over maintenance of some municipal facilities, and performing some services (such as snow removal from side streets and cul-de-sacs) that were formerly done by city workers. For city council members, these privatization policies were based on economic considerations that were independent of any ethical ones.

We also think it appropriate to include in this category some issues where a few officials claimed that ethics was "somewhat important," but that importance seemed to lie in citing an ethical principle to justify an outcome that was largely driven by other considerations. For example, a downtown waterfront development, including a new sports arena, was proposed in Stockton, and officials stressed that their support was based on economic considerations, but some also cited utilitarian justifications ("the project would benefit most city residents") and the benefits of investing in public amenities, no doubt to justify their decision.

On about a third of the issues, ethical considerations seemed to be "somewhat important" to the stances that officials took, and thus were more than post hoc justifications for decisions made on other grounds. A number of economic development and economic regulation decisions illustrate this pattern. The redevelopment of downtown KCMO was embraced by the City Council primarily on the basis of economic considerations, and Mayor Kay Barnes and the Council did not fail to provide a long list of justifications citing how the many public investments were "good for the city," but council support for the overall plan was strengthened by its including not just new 
Schumaker, P. and Kelly, M. (2012), "Ethics Matter: The Morality and Justice Principles of Elected City Officials and their Impact of Urban Issues." Journal of Urban Affairs, 34: 231-253. Publisher's Official Version available at:

http://dx.doi.org/10.1111/j.1467-9906.2011.00583.x Open Access version: http://kuscholarworks.ku.edu/dspace/.

office and commercial buildings, but such public amenities as a sports arena and a performing arts center. Support of black council members was also secured by including affirmative action provisions requiring developers, contractors, and the new businesses to include minorities in their work forces. It seems safe to infer that the principles of investing in public amenities and of enhancing diversity were somewhat important in shaping the specifics of what was essentially an economically-driven facelift of downtown KCMO. In KCK, the development of Village West around a NASCAR Speedway, facilitated by providing 30-year tax abatements to the many businesses locating there, was also largely a matter of economics, and utilitarian arguments about broad community benefits were used as justifications. But as in $\mathrm{KCMO}$, affirmative action justice principles were used to ensure minority contractor and worker participation. And KCK officials faced another justice consideration. Over a hundred family homes and farms occupied the initial 400-acre footprint of this development, and the consolidated city/county government had to use its powers of eminent domain to acquire the property. The Supreme Court had not yet issued its Kelo v. New London ruling (2005) upholding the use of eminent domain to facilitate private investments having public benefits, and thus its use in this case was highly controversial. The Council thus "bent over backward" to treat the displaced families fairly, for example by compensating them at rates $125 \%$ of market value. Whether councilmember decisions in this regard reflected real justice concerns or were simply an expedient means of pursuing economic objectives is hard to determine, but most officials claimed to be moved by the notion that justice required generous compensation.

A different illustration of an issue where ethics was "somewhat important" was an ordinance that came before the KCMO City Council to ban smoking in bars, restaurants, and other public places. A few officials were passionate advocates of such a ban, claiming that utilitarian public 
Schumaker, P. and Kelly, M. (2012), "Ethics Matter: The Morality and Justice Principles of Elected City Officials and their Impact of Urban Issues." Journal of Urban Affairs, 34: 231-253. Publisher's Official Version available at:

http://dx.doi.org/10.1111/j.1467-9906.2011.00583.x Open Access version: http://kuscholarworks.ku.edu/dspace/.

health justifications should be the only consideration. But most officials thought that such considerations had to be weighed against others. Some "hesitant" officials claimed that individual choices had to be respected, and that a complete ban would make government less than neutral on what is largely a private matter; they argued that existing ordinances requiring both smoking and non-smoking sections were adequate. A larger number of hesitant officials thought that economic considerations were crucial. They argued that banning smoking in Kansas City bars and restaurants would prompt business to flow outside the city into suburbs where smoking was allowed. This led to adoption of an ordinance that called for its implementation only when most surrounding cities also adopted no smoking bans. Officials thus subordinated ethical concerns to economic ones, though their ethical concerns were realized in 2010 when the ban went into effect as other communities passed similar laws.

Ethics seemed "significantly important" in the resolution of about a fifth of our issues. One such example comes from St. Joes whose depressed economy made it receptive to a proposal in 2000 by a national company to locate a large pork processing plant in the city's abandoned stockyards. As officials considered the proposal, ethical objections emerged. The applicant was thought to be negligent on various environmental, health, and labor matters. Rather than supply well-paying jobs for existing residents, council members feared that the applicant would pay minimal wages for non-union jobs that would be filled largely by migrant workers. They thus sought alternative proposals, ultimately using Tax Increment Financing to attract Premium Pork to locate its corporate headquarters in the city, build a processing plant that, though smaller than the original proposal, was "state-of-the-art," and employ between one and two thousand union jobs for "young and working class" citizens at decent wages. Because the council thought that the Premium Pork proposal was better than the previous one on ethical grounds - it scored better in the 
Schumaker, P. and Kelly, M. (2012), "Ethics Matter: The Morality and Justice Principles of Elected City Officials and their Impact of Urban Issues." Journal of Urban Affairs, 34: 231-253. Publisher's Official Version available at:

http://dx.doi.org/10.1111/j.1467-9906.2011.00583.x Open Access version: http://kuscholarworks.ku.edu/dspace/.

utilitarian calculus and it promised to improve the condition of some the less-well residents in the community - choosing the Premium Pork proposal was "a no-brainer."

On about 15 percent of the issues, ethical considerations dominated other considerations. The issue of passing a living-wage ordinance had simmered for years in Lawrence, with "Chamber-ofCommerce-dominated" Commissions arguing that economic considerations constrained adoption; for such commissioners, passage of any living-wage ordinance would reinforce the city's reputation as hostile to business and deter mobile capital from moving to Lawrence and perhaps prompt some Lawrence businesses to relocate in more business-friendly communities in Johnson County, the environs of Overland Park 20 miles east. In 2003, passage of a living-wage ordinance was the centerpiece of an ad hoc electoral coalition (Progressive Lawrence) that managed to gain control of the Commission. Though they had the votes to pass as stringent of a living-wage ordinance as they wanted, they recognized that they had to secure widespread acceptance of any law if it were to endure beyond the next election. They thus worked closely with the Chamber and those remaining Commissioners associated with the Chamber to educate them about the community benefits and justice of living-wage ordinances, and agreed to limitations on the reach of their proposal that made it acceptable to their economic concerns. While ethical considerations dominated the passage and continuing implementation of the living wage issue, members of the Progressive coalition had to yield somewhat to economic constraints.

Ethics played an even greater role when Topeka considered passing a gay-rights law in 2002. Topeka is home of Fred Phelps, pastor of the Westburo Baptist Church, who has gained national infamy for leading his family and followers in anti-gay demonstrations at various ceremonies (such as military funerals) that he feels condones "sinful sodomy." Spurred by his antics, a citizen advocacy group sought to include gay, lesbian, bisexual, and transsexual (GLBT) citizens in the 
Schumaker, P. and Kelly, M. (2012), "Ethics Matter: The Morality and Justice Principles of Elected City Officials and their Impact of Urban Issues." Journal of Urban Affairs, 34: 231-253. Publisher's Official Version available at:

http://dx.doi.org/10.1111/j.1467-9906.2011.00583.x Open Access version: http://kuscholarworks.ku.edu/dspace/.

city's non-discrimination ordinances. Topeka councilmembers agreed that this was an issue where ethics was far and away the most important consideration, but they disagreed over ethical principles. A minority felt strongly that the justice principle of combating bias should be the determining factor. But a slim majority felt equally strongly that dominant religious and cultural understandings in the community viewed homosexually as a moral abomination, and that the city's passage of a gay-rights bill would be another step toward moral decline. Our research does not permit us to say what are the dominant religious and cultural beliefs in Topeka. All we can say is that in this case, a certain moral conception trumped a widely-accepted principle of justice. By pointing out that "morality matters," we in no way mean to suggest that ethical outcomes are advanced by a politics that capitalizes on moral principles that are held by intolerant officials or publics or that are used as wedge issues flaming culture wars. ${ }^{\mathrm{xvi}}$

Finally, did we encounter any cases where admirable ethical principles were unquestionably decisive? Many people have been told stories of solitary politicians who dig deep into their ethical consciousness and cast the deciding vote to prevent some ignoble outcome, but we cannot point to any such cases here. Indeed, we doubt that any rigorous social science could do so, given that the particular ethical judgment of that person identified as the key "swing voter" is of no greater significance in democratic outcomes than the stances of other voters whose diverse judgments initially created the deadlock where some decisive vote needed to be cast, given the difficulty of ascertaining the causal importance of various other considerations that accompany what might appear to be an ethically-based decision, and given the value judgments involved.

In political life generally, and in urban politics specifically, important ethical determinations are made by collectivities more than by individuals. In our study, about ten issues arose and were resolved because city councilmembers consensually agreed to a policy decision because they 
Schumaker, P. and Kelly, M. (2012), "Ethics Matter: The Morality and Justice Principles of Elected City Officials and their Impact

shared ethical concerns that prompted them to act regardless of any economic, political, or cultural constraint. And in some of these cases, citizens seem to have shared in that consensus. When swastikas and graffiti containing racist slogans appeared in $\mathrm{KCK}$, its officials quickly passed a hate-crime ordinance based on a variety of moral and justice principles that all officials affirmed. When cuts were made in the Missouri and federal safety net, KCMO officials, motivated by various need-based justice principles placed before voters a referenda to increase property taxes to pay for indigent health care programs; over 60 percent approved the measure. When federal grants for public transportation became available, Lawrence commissioners acknowledged that the absence of any municipal bus system was a community problem that particularly hurt its most disadvantaged citizens, and they created a limited " $T$ " service, which they expanded throughout the first decade of the $21^{\text {st }}$ century. When funding became problematic, commissioners submitted to voters a sales tax increase to support the bus system, and it passed easily in 2010 . Throughout this period, commissioners - and most candidates for the commission - have supported the T. Even though they generally admit that it's not very viable economically, they share a consensus that the system is both good for the community and furthers principles of justice.

\section{Conclusions}

Urban policymaking involves officials believing that their various moral and justice concerns can be furthered by certain policy outcomes. One of their central tasks is to convince other officials that certain ethical principles are at stake on particular issues and that such ethical principles are sufficiently important that they ought to be embodied in urban policymaking. At least some of the time this is the case. We do not deny that urban policymaking also reflects the power and interests of various actors, economic constraints and requirements, jurisdictional limitations and all the other factors stressed by most urban theory and research. We do not deny 
Schumaker, P. and Kelly, M. (2012), "Ethics Matter: The Morality and Justice Principles of Elected City Officials and their Impact

that officials are sometimes power wielders on behalf of specific interests, ideologues, or prisoners of their environments. But sometimes they act as moral agents, and sometimes ethics matters.

By positing the thesis that ethics matter, we do not urge a grand new perspective for the study of urban politics. Pluralists, regime theorists, and other important urban paradigms all acknowledge that political leaders make important decisions that may be independent of various constraints. What we offer is a framework that scholars working within these paradigms can use for thinking about the alternative principles of morality and justice that are the ethical reasons why officials seek to limit the importance of constraints and choose outcomes that reflect what they think are generally good for the community and fair to various individuals and groups within it. We also show that ethical matters can be studied empirically in ways that can complement other analyses of urban policy outcomes.

Whatever our larger theoretical perspectives, recognizing the importance of ethical judgments might encourage us to ask a host of questions about the role of ethics in urban policymaking. What kinds of ethical concerns are brought to bear on various issues? Who raises such concerns and who is moved by them? What kinds of ethical concerns are most likely to derail proposals? What kinds of ethical concerns are most easily incorporated into proposals, producing "better" modifications of them? What kinds of ethical concerns are most likely to be ignored? Under what conditions do ethics matter most? Urban research can profit by addressing such questions. We hope others will join us in seeking to better understand when, how, and why ethics matter. 
Schumaker, P. and Kelly, M. (2012), "Ethics Matter: The Morality and Justice Principles of Elected City Officials and their Impact

${ }^{\mathrm{i}}$ A growing body of psychological and evolutionary research points to the role of normative evaluations in human behavior generally. In his summary of some of this research, Brooks (2011: 21) notes that "Emotion assigns values to things, and reason can only make choices on the basis of these valuations."

ii Judd (2005) discusses the concern that in urban research, "scholarship, advocacy, and ideology have become hopelessly entangled."

iii This conception parallels a rigorous conception of power: that getting what one wants is not sufficient to say one has power; to have power, one must get what one wants in the face of opposition.

iv The assumption that people have autonomously-derived desires to be treated as independent variables has been strongly contested in a wide range of political theory, including that of Bachrach and Baratz (1962), Lukes (1974: 21-25) and Sandel (1984). ${ }^{v}$ An interesting question for urban analysis concerns the possible differential constraints imposed by local, national, and global markets. Many officials and scholars believe that expanding global markets enhance constraints on local officials. While this belief is certainly plausible, some research (such as that by Savitch and Kantor, 2002) suggests caution about over-generalizing in this regard.

vi Ethical pluralism has given rise to a new generation of (reconstructed) pluralist political theory, as expressed in the work of Walzer (1983), Rawls (1993), Eisenberg (1995), Kekes (2000), Galston (2004), Connolly (2005), and Schlosberg (2006). 
Schumaker, P. and Kelly, M. (2012), "Ethics Matter: The Morality and Justice Principles of Elected City Officials and their Impact

vii There is, of course, a vast literature making this point, ranging from Schumpeter's (1942: 250-55) skepticism of citizen's ability to reach agreement on the contents of the common good to Sandel's (1996: 318-321) insistence on the desirability of seeing its contents as contestable.

vii We do not insist that political morality and political justice are the only ethical considerations that officials may consider. For example, as we shall discuss at the beginning of section 4, they may be concerned with how political decisions affect citizenship. Our concern is not to provide an exhaustive set of normative principles, but only to examine a significant set of such principles.

ix Most officials included in our data set were from a particular council within our sample cities. However, a few persons who had served on a previous council were also interviewed when they were identified as playing key roles in the concrete issues under investigation. Most interviews within particular cities were conducted within a 3-6 month period when officials were not subject to electoral pressures.

Among the factors contributing to extended time-period for completing the data collection were (a) the need to accommodate officials' busy schedules in setting up the two-stage interviews, (b) the need to complement the interviews with other contextual research, and (c) the need to await the resolution of certain issues that had arisen but remained unresolved, even after interviews were completed. In such circumstances, call-back telephone interviews were sometimes used.

$\mathrm{x}$ When this happened, we tried to listen to their principles and note how these principles departed from those we presented, but in the end we tried to get as much consistency as possible across officials. This was done by discussing various meanings and applications of 
Schumaker, P. and Kelly, M. (2012), "Ethics Matter: The Morality and Justice Principles of Elected City Officials and their Impact

these principles, and then prompting officials to indicate their degree of support for a common set of moral meanings that the principles were intended to express.

xi Many officials were well aware of the argument associated with Peterson (1981) that local communities are poorly positioned in the federal system to provide welfare.

xii Of course, some concrete issues are difficult to classify using this typology, as much politics occurs over such labeling (Riker, 1986). For example, living wage ordinances can be seen as policies to provide public assistance to low-income families, as economic regulations, and as (usually adverse) economic development policies. Nevertheless, our classification of concrete issues is not arbitrary but reflects the judgments of the officials themselves. The issues identified for study were based on officials providing their views of the most important public provision, economic development, public assistance, economic regulation, and social regulation policies that arose recently in their communities. They also identified and we also studied a few additional issues - mostly about procedural and personnel matters - that did not fit well into one of these domains, but these issues are ignored in this paper.

xiii The unequal number of cases across domains in Table 5 is due to our usually considering two issues involving public provision, economic development, and public assistance in each city, but only one case of economic regulation and social regulation in each city. Also some officials did not participate in selected issues that were largely resolved prior to their assuming office. xiv Discussion of the differential importance of other considerations across policy domains would take us outside the focus of this paper, but readers might find interesting such findings as public preferences being most important on issues of social regulation and least important on issues of public assistance. 
Schumaker, P. and Kelly, M. (2012), "Ethics Matter: The Morality and Justice Principles of Elected City Officials and their Impact of Urban Issues." Journal of Urban Affairs, 34: 231-253. Publisher's Official Version available at:

http://dx.doi.org/10.1111/j.1467-9906.2011.00583.x Open Access version: http://kuscholarworks.ku.edu/dspace/.

${ }^{\mathrm{xv}}$ To classify issues by the degree to which ethics mattered in their resolution, we averaged the assessments of all participating officials on each issue, yielding an overall "ethics matter" score for each issue. If an issue had an average score of less than 1.5 , the majority thought ethics were at best minor considerations, and reviewing these cases provided little reason for suggesting that ethical considerations affected the outcome. Subsequent determinations about issues where ethics mattered more were made in the same manner. Since some researcher judgment goes into these assessments, we are uncomfortable reporting precise estimates of the percentage of issues that fall into various categories and instead use more general language.

xvi Among the many works that could be cited about the problematic nature of moralistic politics are those of Bennett and Shapiro (2002) and Wolfe (2006: 4-7). 
Table 1

Sample of cities and selected characteristics

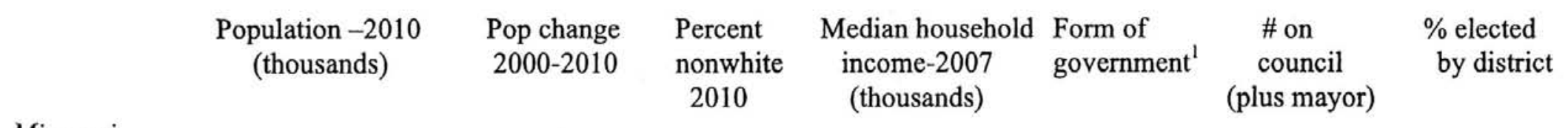

\section{Missouri}

$\begin{array}{lrrr}\text { Kansas City } & 460 & +4 \% & 41 \\ \text { Lee's Summit } & 91 & +29 \% & 14 \\ \text { Raytown } & 30 & -4 \% & 32 \\ \text { St. Joseph } & 77 & +4 \% & 12\end{array}$

56
82
47
52

$\mathrm{CM}$
$\mathrm{CM}$
$\mathrm{MC}$
$\mathrm{CM}$

$\begin{array}{rl}12+1 & 46 \\ 8+1 & 88 \\ 10+1 & 91 \\ 8+1 & 56\end{array}$

\section{Kansas}

\begin{tabular}{|c|c|c|c|c|c|c|}
\hline Kansas City & 146 & $-1 \%$ & 48 & 44 & $\mathrm{CM}$ & $10+1$ \\
\hline Overland Park & 173 & $+15 \%$ & 16 & 91 & $\mathrm{MC}$ & $12+1$ \\
\hline Topeka & 127 & $+3 \%$ & 24 & 52 & $\mathrm{MC}$ & $8+1$ \\
\hline Lawrence & 88 & $+9 \%$ & 18 & 62 & $\mathrm{CM}$ & 5 \\
\hline
\end{tabular}

\section{California}

\begin{tabular}{|c|c|c|c|c|c|c|}
\hline Berkeley & 113 & $+10 \%$ & 41 & 87 & $\mathrm{CM}$ & $8+1$ \\
\hline Richmond & 104 & $+5 \%$ & 69 & 66 & $\mathrm{CM}$ & $8+1$ \\
\hline Stockton & 292 & $+19 \%$ & 63 & 64 & $\mathrm{CM}$ & $6+1$ \\
\hline Lodi & 62 & $+9 \%$ & 26 & 51 & $\mathrm{CM}$ & 5 \\
\hline
\end{tabular}

\footnotetext{
${ }^{1} \mathrm{CM}=$ Council-Manager (reformed); $\mathrm{MC}=$ Mayor-Council (unreformed)
} 
Schumaker, P. and Kelly, M. (2012), "Ethics Matter: The Morality and Justice Principles of Elected City Officials and their Impact of Urban Issues." Journal of Urban Affairs, 34: 231-253. Publisher's Official Version available at:

http://dx.doi.org/10.1111/j.1467-9906.2011.00583.x Open Access version: http://kuscholarworks.ku.edu/dspace/.

Table 2

\section{Elected Officials' Overall Attributions of the Importance of their Morality and Justice Principles: City and State Differences ${ }^{1}$}

$\begin{array}{lrrr} & \text { N } & \text { Mean } & \text { Standard Deviation } \\ \text { Missouri } & \mathbf{3 9} & \mathbf{2 . 0 6} & \\ \quad \text { Kansas City } & 12 & 2.10 & \mathbf{1 . 6 5} \\ \quad \text { Lee's Summit } & 9 & 2.29 & 1.76 \\ \quad \text { Raytown } & 10 & 1.68 & 1.78 \\ \quad \text { St. Joseph } & 8 & 2.20 & 1.38 \\ \text { Kansas } & & & 1.60 \\ \quad \text { Kansas City } & \mathbf{3 6} & \mathbf{2 . 2 2} & \\ \quad \text { Overland Park } & 9 & 2.60 & \mathbf{1 . 7 6} \\ \quad \text { Topeka } & 11 & 1.19 & 1.61 \\ \quad \text { Lawrence } & 9 & 3.26 & 1.39 \\ \quad \text { California } & 7 & 2.10 & 1.80 \\ \quad \text { Berkeley } & & & 1.52 \\ \quad \text { Richmond } & \mathbf{2 0} & \mathbf{3 . 3 4} & \\ \quad \text { Stockton } & 5 & 4.00 & \mathbf{1 . 9 8} \\ \quad \text { Lodi } & 6 & 3.31 & 1.73 \\ \quad 6 & 2.25 & 2.16 \\ \text { Total } & 4 & 3.89 & 2.21 \\ \quad & \mathbf{9 5} & \mathbf{2 . 2 8} & 1.02 \\ & & & \mathbf{1 . 7 8}\end{array}$

${ }^{1}$ The 95 officials $(\mathrm{N})$ in our 12 cities indicated the extent to which their own principles of morality and justice impacted the most important and/or controversial issues that arose in each of these communities. Between 7 and 9 issues were analyzed in each community, leading to a total of 93 issues being studied. The above scores are based on 655 cases altogether (some officials did not participate in some decisions). If officials said that such principles played no role in their decisions ( $n=166)$, the case was scored "0." If officials said that ethical principles played a minor role $(n=87)$, the case was scored " 1. " If officials said that such principles were "somewhat important" $(\mathrm{n}=111)$, the case was scored as "2." If officials said that such principles played a significant role $(n=114)$, the case was scored as " 3 ." If officials said that such principles were "very important" ( $n=87)$, the case was scored as "4." If officials said that such principles were "the most important factor" in their decisions $(n=90)$, the case was scored as " 5. " 
Schumaker, P. and Kelly, M. (2012), "Ethics Matter: The Morality and Justice Principles of Elected City Officials and their Impact of Urban Issues." Journal of Urban Affairs, 34: 231-253. Publisher's Official Version available at:

http://dx.doi.org/10.1111/j.1467-9906.2011.00583.x Open Access version: http://kuscholarworks.ku.edu/dspace/.

\section{Table 3}

\section{Various principles of morality: Overall support and variation among urban officials, as well as correlations between support for each principle and self-defined ideology}

Promote good citizenship. Public officials should ensure that their policies promote aware, informed, community-regarding, and active citizens

Apply utilitarian reasoning. Decisions should be based on the "greater good of the greater number," as officials should not be overly concerned about who most benefits and who is most hurt when the greater good is advanced

Practice neutrality. Citizens should be granted freedom to pursue their own conceptions of the good life, as long as they do not harm others, and officials should avoid legislating morality

Reflect dominant religious beliefs. City policies should reflect and further widely held religious values

Reflect local cultural values. City policies should reflect those traditional values that are dominant locally

Regulate land use. Various uses of private property should be restricted for public purposes

Promote economic growth. Priority should be given to promoting economic development, even at the expense of other social goals

Practice laissez-faire. Public officials should minimize interventions in the free market

Subsidize new businesses. Priority should be given to providing tax incentives and other subsidies to new businesses that promise to generate more jobs and wealth within the community

Improve the physical infrastructure. Priority should be given to improving roads, bridges, sewers, and other public facilities on which the community depends

Improve public services. Priority should be given to improving public safety, trash collection, and other basic services

Invest in public amenities. Officials should invest public funds in such things as Parks, sports facilities, and museums that add to quality of life

Minimize taxation. Public officials should lower taxes even if that reduces city services
Mean SD. $r$

$\begin{array}{lll}4.75 \quad .78 & -.13\end{array}$

$3.61 \quad 1.16 \quad-.23$

$4.06 \quad 1.14 \quad .16$

$\begin{array}{lll}1.84 & 1.07 & -.29\end{array}$

$2.97 \quad 1.36 \quad-.35$

$\begin{array}{lll}4.00 \quad .99 & .10\end{array}$

$\begin{array}{lll}3.46 & .92 & -.23\end{array}$

$\begin{array}{lll}3.15 & 1.16 & -.38\end{array}$

$\begin{array}{lll}3.17 & 1.15 & -.08\end{array}$

$4.44 \quad .71 \quad .06$

$4.06 \quad .91 \quad .22$

$\begin{array}{lll}3.82 & .98 \quad .34\end{array}$

$2.51 \quad 1.00 \quad-.23$

- The mean and standard deviations (SD) in support for each principle were assessed using 5-point ordinal scales, ranging from strongly opposed (1) through neutral (3) to strongly supportive (5).

- Pearson correlation coefficients report relationships between support for various justice principles and self-defined ideology, using an ordinal scale ranging from strongly conservative (1) to strongly liberal (5). Kendall's tau and Spearman's rho for ordinal-level measures produced correlation coefficients with only minor and substantively inconsequential differences than those reported here. 
Schumaker, P. and Kelly, M. (2012), "Ethics Matter: The Morality and Justice Principles of Elected City Officials and their Impact of Urban Issues." Journal of Urban Affairs, 34: 231-253. Publisher's Official Version available at:

http://dx.doi.org/10.1111/j.1467-9906.2011.00583.x Open Access version: http://kuscholarworks.ku.edu/dspace/.

\section{Table 4 \\ Various principles of justice: Overall support and variation among urban officials, as well as correlations between support for each principle and self-defined liberalism} Distribute equally. City resources and services should be distributed equally,
ignoring unequal needs or contributions

Combat bias. Local laws should be passed and enforced that prevent racial, gender, and other such forms of discrimination

Pursue equal opportunity. Local laws and governmental practices should help minorities, women, and other such groups compete fairly for the most desired things in life

Enhance diversity. Government should consider race and other such social characteristics in order to promote social diversity

Focus on the least well-off. Policies should be adopted that improve the conditions of citizens having natural and social disadvantages, and policies should be avoided that harm such citizens

Provide welfare rights. Local policies and programs should recognize that every resident has a right to minimal and perhaps greater levels of health care, nutrition, shelter and other such human needs, even if they are unable to purchase them

Provide floors. Programs should be adopted or publicly funded that ensure that no citizen lacks the minimal goods he or she needs

Avoid redistribution. Public officials should avoid redistributing wealth and other resources that reflect individual choices and efforts in free markets

Reward talent. When distributing policy benefits and burdens, officials should reward those with the most talent

Reward social contribution. When distributing policy benefits and burdens, officials should reward those who contribute most to the community

Reward market contribution. When distributing policy benefits and burdens, officials should reward those who contribute most to the marketplace

Reward effort. When distributing policy benefits and burdens, officials should reward those who make the greatest effort

Reward tax contribution. When distributing policy benefits and burdens, officials should reward those who contribute the most taxes
Mean SD $\quad$.

$\begin{array}{lll}2.52 & 1.26 & -.08\end{array}$

$\begin{array}{lll}4.77 \quad .68 & .09\end{array}$

$\begin{array}{lll}4.33 & .98 \quad .22\end{array}$

$\begin{array}{lll}3.22 & 1.53 & .41\end{array}$

$\begin{array}{lll}3.56 & 1.06 \quad .28\end{array}$

$\begin{array}{lll}3.69 & 1.13 & .19\end{array}$

$3.62 \quad 1.14 \quad .31$

$2.77 \quad 1.38 \quad-.36$

$\begin{array}{lll}1.95 & 1.12 \quad .06\end{array}$

$\begin{array}{lll}2.38 & 1.13 & .09\end{array}$

$2.16 \quad 1.09 \quad-.18$

$\begin{array}{lll}2.86 & 1.35 & .08\end{array}$

$\begin{array}{lll}1.69 & 1.01 \quad .00\end{array}$

- The mean and standard deviations (SD) in support for each principle were assessed using 5-point ordinal scales, ranging from strongly opposed (1) through neutral (3) to strongly supportive (5).

- Pearson correlation coefficients report relationships between support for various justice principles and self-defined ideology, using ordinal scales ranging from strongly conservative (1) to strongly liberal (5). Kendall's tau and Spearman's rho for ordinal-level measures produced correlation coefficients with only minor and substantively inconsequential differences than those reported here. 
Schumaker, P. and Kelly, M. (2012), "Ethics Matter: The Morality and Justice Principles of Elected City Officials and their Impact of Urban Issues." Journal of Urban Affairs, 34: 231-253. Publisher's Official Version available at:

http://dx.doi.org/10.1111/j.1467-9906.2011.00583.x Open Access version: http://kuscholarworks.ku.edu/dspace/.

Table 5

\section{Extent to which officials perceived various considerations as important bases of their votes ${ }^{1}$}

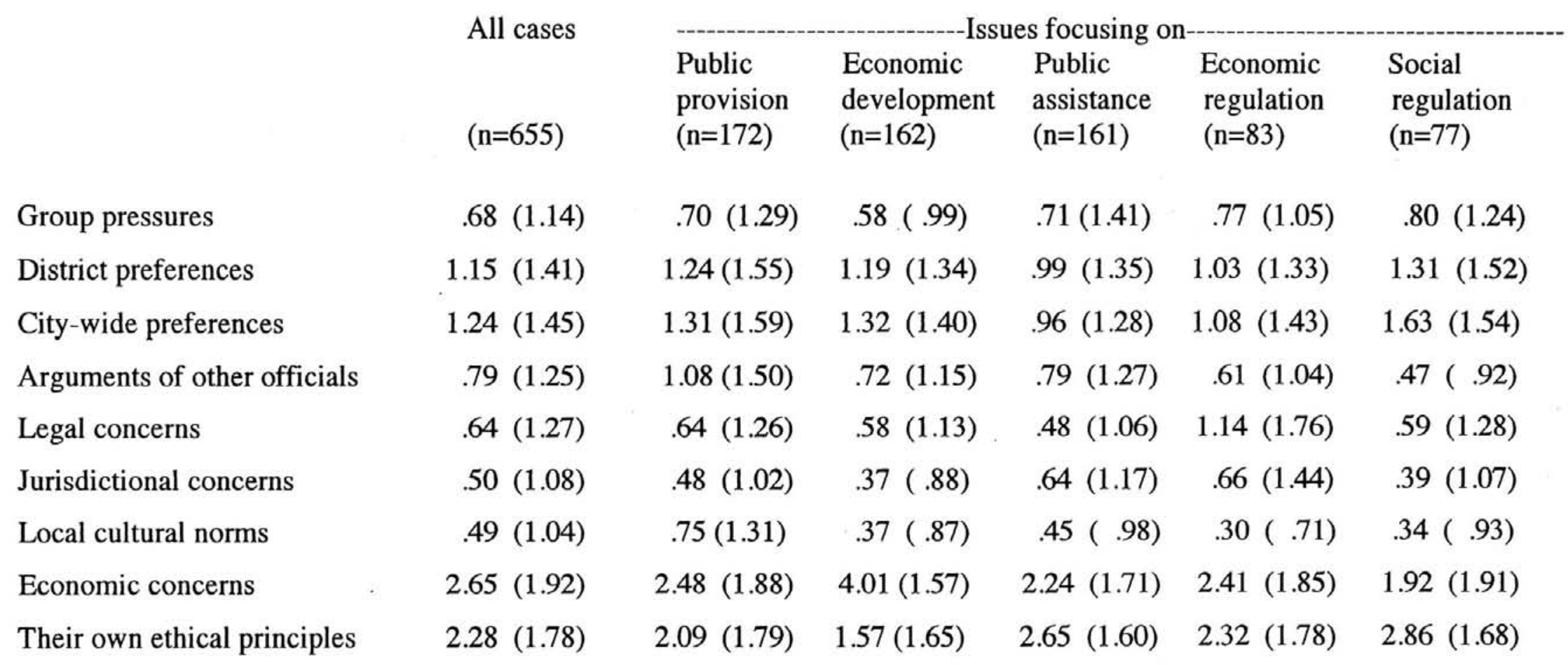

\footnotetext{
${ }^{1}$ Mean scores of the importance that officials attributed to various considerations, using the scale indicated for Table 2 . Standard deviations are provided in parentheses.
} 
Schumaker, P. and Kelly, M. (2012), "Ethics Matter: The Morality and Justice Principles of Elected City Officials and their Impact of Urban Issues." Journal of Urban Affairs, 34: 231-253. Publisher's Official Version available at:

http://dx.doi.org/10.1111/j.1467-9906.2011.00583.x Open Access version: http://kuscholarworks.ku.edu/dspace/.

\section{References}

Bachrach, Peter, and Morton Baratz. 1962. "Two Faces of Power." American Political Science Review 57 (4): 947-5 2.

Bennett, Jane, and Michael Shapiro. 2002. The Politics of Moralizing. New York: Routledge.

Berlin, Isaiah. 1954. Historical Inevitability. London: Oxford University Press.

Brooks, David. 2011. The Social Animal. New York: Random House.

Browning, Rufus P, Dale Rogers Marshall, and David H. Tabb. Protest is Not Enough. Berkeley: University of California Press.

Dahl, Robert A. 1961. Who Governs? New Haven, CN: Yale University Press.

DeLeon, Richard E. 1992. Left Coast City: Progressive Politics In San Francisco 1975-1991.

Lawrence: University Press of Kansas

Dye, Thomas. 1966. Politics, Economics, and the Public. Chicago: Rand McNally.

Eisenberg, Abigail. 1995. Reconstructing Political Pluralism. Albany: State University of New York Press.

Elkin, Stephen L. 1987. City and Regime in the American Republic. Chicago: University of Chicago Press.

Eulau, Heinz, and Kenneth Prewitt. 1974. Labyrinths of Democracy. Indianapolis, IN: BobbsMerrill

Friedman, Benjamin. 2005. The Moral Consequences of Economic Growth. New York: Vintage Books.

Frohlich, Norman, and Joel Oppenheimer. 1992. Choosing Justice: An Experimental Approach to Ethical Theory. Berkeley: University of California Press. 
Schumaker, P. and Kelly, M. (2012), "Ethics Matter: The Morality and Justice Principles of Elected City Officials and their Impact of Urban Issues." Journal of Urban Affairs, 34: 231-253. Publisher's Official Version available at:

http://dx.doi.org/10.1111/j.1467-9906.2011.00583.x Open Access version: http://kuscholarworks.ku.edu/dspace/.

Galston, William. 2004. Value Pluralism and Liberal Political Theory. New York: Cambridge University Press.

Gutmann, Amy, and Dennis Thompson, 2004. Deliberative Democracy. Princeton NJ: Princeton University Press.

Held, Virginia. 1970. The Public Interest and Individual Interests. New York: Basic Books.

Henig, Jeffrey, et al. 1999. The Color of School Reform. Princeton NJ: Princeton University Press.

Henig, Jeffrey, and Michael Rich. 2004. Mayors in the Middle. Princeton NJ: Princeton University Press.

Hunter, Floyd. 1953. Community Power Structure. Chapel Hill, NC: University of North Carolina Press.

Jones, Bryan D., Lynn Bachelor, and Carter Wilson. 1986. The Sustaining Hand. Lawrence: University Press of Kansas.

Judd, Dennis. 2005. "Everything is Going to Hell: Urban Scholars as End-times Prophets," Urban Affairs Review 2 (2): 119-31.

Judge, David, Gerry Stoker, and Harold Wolman. 1985. Theories of Urban Politics. Thousand Oaks CA: Sage.

Kekes, John. 2000. Pluralism in Philosophy: Changing the Subject. Ithica, NY: Cornell University Press.

Kingdon, John W. 1989. Congressmen's Voting Decisions, $3^{\text {rd }}$ edition. Ann Arbor: University of Michigan Press.

Lukes, Steven. 1974. Power: A Radical View. New York: Macmillan. 
Schumaker, P. and Kelly, M. (2012), "Ethics Matter: The Morality and Justice Principles of Elected City Officials and their Impact of Urban Issues." Journal of Urban Affairs, 34: 231-253. Publisher's Official Version available at:

http://dx.doi.org/10.1111/j.1467-9906.2011.00583.x Open Access version: http://kuscholarworks.ku.edu/dspace/.

Lowi, Theodore. 1964. "American Business, Public Policy, Case Studies, and Political Theory.” World Politics 16 (July): 677-715.

MacIntyre, Alasdair. 1999. "Social Structures and their Threat to Moral Agency." Philosophy 74 (3): $311-329$

Madsen. Richard, and Tracy B. Strong. 2003. "Three Forms of Ethical Pluralism," pp. 1-21 in Madsen and Strong (ed.), The One and the Many, Princeton: NJ: Princeton University Press

Mele, Alfred. 2009. Effective Intentions: The Power of Conscious Will. New York: Oxford University Press.

Mill, John Stuart. 1859. On Liberty. Widely available in the public domain.

Mollenkopf, John H. 1983. The Contested City. Princeton: NJ: Princeton University Press.

Nickel, James. 2007. Making Sense of Human Rights. Malden MA: Blackwell Publishing.

Nozick, Robert. 1974. Anarchy, State, and Utopia. New York: Basic Books.

Ostrom, Elinor. 1990. Governing the Commons. New York: Cambridge University Press.

Peterson, Paul. 1981. City Limits. Chicago: University of Chicago Press.

Rawls, John. 1999. A Theory of Justice, revised edition. Cambridge MA: Harvard University Press.

Rescher, Nicholas. 1982. Distributive Justice. Washington DC: University Press of America. Riker, William. 1986. The Art of Political Manipulation. New Haven: Yale University Press.

Sandel, Michael. 1996. Democracy's Discontents. Cambridge MA: Harvard University Press. Sandel, Michael. 1984. The Procedural Republic and the Unencumbered Self." Political Theory 12 (1): 81-96. 
Schumaker, P. and Kelly, M. (2012), "Ethics Matter: The Morality and Justice Principles of Elected City Officials and their Impact of Urban Issues." Journal of Urban Affairs, 34: 231-253. Publisher's Official Version available at:

http://dx.doi.org/10.1111/j.1467-9906.2011.00583.x Open Access version: http://kuscholarworks.ku.edu/dspace/.

Sapotichne, Joshua, Bryan D. Jones, and Micelle Wolfe. 2007. "Is Urban Politics a Black Hole?

Analyzing the Boundary Between Political Science and Urban Politics." Urban Affairs Review 43 (1): 76-106.

Savitch, H.V. and Paul Kantor. 2002. Cities in the International Marketplace. Princeton NJ:

Princeton University Press.

Schneider, Mark, Paul Teske, and Michael Mintrom. 1995. Public Entrepreneurs: Agents for

Change in American Politics. Princeton NJ: Princeton University Press.

Schlosberg, David. 2006. “The Pluralism Imagination," pp. 142-160 in John Dryzek, Bonnie

Honig, and Anne Phillips (eds.) The Oxford University Press Handbook of Political

Theory. New York: Oxford University Press.

Schumaker, Paul. 2008. From Ideologies to Public Philosophies. Malden

Scott, John T., and Brian H. Bornstein. 2009. "What's Fair in Foul Weather and Fair?

Distributive Justice across Different Allocation Contexts and Goods." Journal of Politics

$71(3): 831-846$.

Sher, George. 1987. Desert. Princeton NJ: Princeton University Press.

Stone, Clarence. 1987. "Urban Regimes, Development Policy, and Political Arrangements," pp.

269-290 in Stone and Heywood Sanders (eds.), The Politics of Urban Development.

Lawrence: University Press of Kansas.

Stone, Clarence. 1989. Regime Politics. Lawrence: University Press of Kansas.

Stone, Clarence. 1993. "Urban Regimes and the Capacity to Govern: A Political Economy

Approach." Journal of Urban Affairs 15 (1): 1-28

Stoker, Laura. 1992. "Interests and Ethics in Politics." American Political Science Review 86 (2)

369-380. 
Schumaker, P. and Kelly, M. (2012), "Ethics Matter: The Morality and Justice Principles of Elected City Officials and their Impact of Urban Issues." Journal of Urban Affairs, 34: 231-253. Publisher's Official Version available at:

http://dx.doi.org/10.1111/j.1467-9906.2011.00583.x Open Access version: http://kuscholarworks.ku.edu/dspace/.

Thompson, James D. 1967. Organizations in Action. New York: McGraw-Hill

Walzer, Michael. 1983. Spheres of Justice. New York: Basic Books.

Waste, Robert. 1986. "Community Power and Pluralist Theory." Pp. 117-138 in Waste (ed.), Community Power: New Directions for Future Research. Beverly Hills, CA: Sage.

Wolfe, Alan. 2006. Does American Democracy Still Work? New Haven CN: Yale University Press. 